LAND AND BOOK:

LITERATURE AND LAND TENURE IN ANGLO-SAXON ENGLAND 
This page intentionally left blank 
SCOTT THOMPSON SMITH

\section{Land and Book:}

Literature and Land Tenure

in Anglo-Saxon England

UNIVERSITY OF TORONTO PRESS

Toronto Buffalo London 
(C) University of Toronto Press 2012

Toronto Buffalo London

www.utppublishing.com

Printed in Canada

ISBN 978-1-4426-4486-1



Printed on acid-free, $100 \%$ post-consumer recycled paper with vegetable-based inks.

\section{Library and Archives Canada Cataloguing in Publication}

Smith, Scott Thompson

Land and book: literature and land tenure in Anglo-Saxon England /

Scott Thompson Smith.

(Toronto Anglo-Saxon series)

Includes bibliographical references and index.

ISBN 978-1-4426-4486-1

1. Land tenure in literature. 2. Land tenure - England - History - To 1500.

3. Land tenure - Law and legislation - England - History. 4. English literature

- Old English, ca. 450-1100 - History and criticism. 5. Latin literature, Medieval and modern - England - History and criticism. I. Title. II. Series: Toronto Anglo-Saxon series.

\section{PR179.L35S65 2012 829'093553 C2012-903934-9}

University of Toronto Press gratefully acknowledges the financial assistance of the Centre for Medieval Studies, University of Toronto, in the publication of this book.

University of Toronto Press acknowledges the financial assistance to its publishing program of the Canada Council for the Arts and the Ontario Arts Council.

\section{Canada Council for the Arts}

Conseil des Arts du Canada

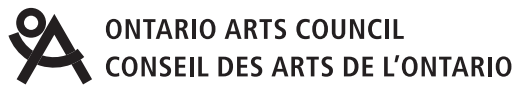

University of Toronto Press acknowledges the financial support of the Government of Canada through the Canada Book Fund for its publishing activities. 
To Dad, in loving memory 
This page intentionally left blank 